\title{
Agronomic performance of upland rice cultivars in the southern region of the state of Tocantins
}

\section{Comportamento agronômico de cultivares de arroz de terras altas na Região Sul do Estado do Tocantins}

\author{
Leila Paula Tonello; Taynar Coelho de Oliveira Tavares ${ }^{2}$; \\ Ricardo de Oliveira Rocha3; Gil Rodrigues dos Santos; \\ Sérgio Alves de Sousa ${ }^{5}$; Rodrigo Ribeiro Fidelis ${ }^{4 *}$
}

\begin{abstract}
Behavioural assessment of cultivars adapted to climate and soil variations is essential for recommending genetic materials to producers, achieving higher profitability, and, mainly, targeting regional growth. The aim of this study was to evaluate the agronomic performance of upland rice cultivars in different cropping periods and Cerrado vegetation soil in the southern region of the state of Tocantins. The experiments were conducted in a field at the Chaparral Farm and at the Experimental Station of the Federal University of Tocantins in the agricultural years of 2008/2009, 2009/2010, 2010/2011, 2011/2012, and 2012/2013 with cultivars BRS-Bonança, BRS-Primavera, and BRSMG-Conai. A randomized block experimental design was used with four replications in a factorial scheme of $3 \times 5$, comprising three genotypes and five years. The evaluated characteristics were as follows: number of days to flowering, plant height, weight of hundred grains, and grain yield. The highest upland rice yield was observed in the cropping period of 2012/13, which also had the highest volume and better distribution of rainfall; flowering time was lesser and greater for BRSMG-Conai and BRS-Bonança cultivars, respectively. The BRS-Primavera cultivar showed the highest grain yield in different years in Cerrado soil in the southern region of the state of Tocantins.
\end{abstract}

Key words: Cerrado. Food safety. Oryza sativa.

\section{Resumo}

A avaliação comportamental de cultivares adaptados às variações edafoclimáticas é essencial para a recomendação de material genético ao produtor, visando maior rentabilidade e, principalmente, almejando o crescimento regional. Objetivou-se com este trabalho avaliar o comportamento agronômico de cultivares de arroz de terras altas em diferentes safras sob solo de vegetação de Cerrado do sul do Estado do Tocantins. Os experimentos foram conduzidos nos anos agrícolas de 2008/2009, 2009/2010, 2010/2011, 2011/2012 e 2012/2013 com as cultivares BRS-Bonança, BRS-Primavera e BRSMGConai. O delineamento experimental foi de blocos casualisados com quatro repetições, num esquema fatorial 3 x 5 , constituído por três genótipos e cinco anos. As características avaliadas foram número de dias para florescimento, altura da planta, massa de cem grãos e produtividade de grãos. As maiores produtividades de grãos de arroz de terras altas foram alcançadas na safra 2012/13, que apresentou maior volume e melhor distribuição da precipitação pluvial; $\mathrm{O}$ tempo de florescimento foi menor e

\footnotetext{
M.e em produção Vegetal, Universidade Federal do Tocantins, UFT, Gurupi, TO, Brasil. E-mail: lptonello@gmaill.com

2 Pesquisadora PNPD, UFT, Gurupi, TO, Brasil. E-mail: taynarcoelho@hotmail.com

3 Discente do Curso de Graduação em Agronomia, UFT, Gurupi, TO, Brasil. E-mail: eng.agricola.ricardo@gmail.com

4 Profs., UFT, Gurupi, TO, Brasil. E-mail: gilrsan@uft.edu.br; fidelisrr@uft.edu.br

${ }^{5}$ Discente do Curso de Doutorado do Programa de Pós-Graduação em Produção Vegetal, UFT, Gurupi, TO, Brasil. E-mail: sergioalves_sousa@hotmail.com

* Author for correspondence
} 
maior para as cultivares BRSMG-Conai e BRS-Bonança respectivamente; A cultivar BRS-Primavera apresentou as maiores produtividades de grãos nos diferentes anos sob solo de vegetação de Cerrado no sul do Estado do Tocantins.

Palavras-chave: Cerrado. Segurança alimentar. Oryza sativa.

\section{Introduction}

Rice (Oryza sativa L.) is one of the main cereals grown and consumed worldwide. It has great economic and social importance in developing countries and is an important source of nutrients. Rice has adapted to different growing conditions, but large fluctuations in its production have been observed. Thus, technological innovations to solve this problem and augment rice productivity and quality are required so that the needs of the population can be fulfilled (NOSSE et al., 2008).

In the tropical regions of Brazil, the largest grain production is in the upland system of the Cerrado areas thus, the rice crop becomes a pioneer in agricultural occupation as an opening crop of farming areas. This is because rice has few nutritional requirements and is tolerant to acidic soils such as the Cerrado soils of Brazil with low water retention (CRUSCIOL et al., 2003a).

The region is also characterized by high seasonality of hydric precipitation, the so-called dry spells (veranicos) that cause large losses in production, since crops under water deficiency conditions undergo physiological, biochemical, and morphological alterations (TERRA et al., 2013).

According to the eleventh grain harvesting survey, conducted by CONAB (2015), the national average grain yield was $5443 \mathrm{~kg} \mathrm{ha}^{-1}$ in the cropping year 2014/2015. The states of Santa Catarina and Rio Grande do Sul are the largest rice producers, together producing $69.37 \%$ of the national harvest in over $50 \%$ of the total area of rice in Brazil. The state of Tocantins is the third-largest producer of irrigated rice, grown in large areas in the regions of Formoso do Araguaia, Confusão Lagoon, Dueré, Cristalândia, and Pium, and upland rice with a likely decrease in planted area because of the replacement of the crop for soybean and corn production.
Heterogeneity in environments in which rice is grown is the result of multiple abiotic stresses such as climate changes and soil fertility. Thus, characteristics and phenotypic and genotypic aspects of the crop are determined directly or indirectly by the action of external factors and are the end result of plant-environment interactions (GUIMARÃES et al., 2008). The whole development of the culture and its gene expression may be linked to internal biochemical stimuli, which differ by the gene interaction in environmental diverse conditions and end up reflecting on final productivity. Breeding depends on plant-environment interaction, and the best morphological and economic characteristics of rice species in different environmental conditions need to be identified (NUNES et al., 2012).

New breeding techniques for viable genetic material under different conditions or in different regions are required for maximum possible gain. The greatest challenge for breeders is to increase food production because of an increase in global consumer demand (SOUSA et al., 2012). Best agricultural practices combined with productive potential and crop breeding are required for increasing crop productivity. Many researchers have verified the importance of identifying genetic materials adapted to diverse environmental conditions (CARGNIN et al., 2008; MORAIS et al., 2008; SOUSA et al., 2012).

Behavioural assessment of cultivars in several years and identification of cultivars adapted to the greatest extent to soil and climatic variations need to be performed for recommending genetic material to producers, who aim for higher profitability and mainly target regional growth (MELO et al., 2007). The State of Tocantins is a region with productive potential and, taking into consideration its strategic location at a country road junction, it can become a corridor for the export of rice and become an 
agricultural trade centre in the region (PIRES et al., 2012). Thus, the aim of this study was to evaluate the agronomic behaviour of upland rice cultivars in Cerrado vegetation soil in the southern region of the state of Tocantins.

\section{Material and Methods}

Assessment of rice cultivar behaviour was performed using experiments in the years 2008/2009, 2009/2010, 2010/2011, 2011/2012, and 2012/2013 in an upland farming system. The 2008/2009 harvest was performed in the Chaparral Farm, located in the municipality of Gurupi $\left(11^{\circ} 40^{\prime}\right.$ south latitude and $49^{\circ} 01^{\prime}$ west longitude; altitude, $280 \mathrm{~m}$ ), and the soil type was a dystrophic red-yellow Oxisol of a sandy textural class. The other four experiments were conducted at the experimental station of the Federal University of Tocantins, University Campus of Gurupi. The 2009/2010 harvest was conducted in an area located at $11^{\circ} 46^{\prime} 12^{\prime \prime} \mathrm{S}$ latitude and $49^{\circ} 02^{\prime} 45^{\prime \prime} \mathrm{W}$ longitude (altitude, $286 \mathrm{~m}$ ); The 2010/2011, $2011 / 12$, and 2012/13 harvests were conducted in an area located at $11^{\circ} 43^{\prime} 45^{\prime \prime} \mathrm{S}$ latitude and $49^{\circ} 04^{\prime} 07^{\prime \prime} \mathrm{W}$ longitude (altitude, $280 \mathrm{~m}$ ). All soils were classified as dystrophic red-yellow Oxisol (EMBRAPA, 2013). According to the Köppen (1948), the climate of the region is the mesothermal type with summer rains and dry winter. Weather data for the referred period of the experiments are shown in Figure 1.

Figure 1. Precipitation $(\mathrm{mm})$ and maximum and minimum temperatures $\left({ }^{\circ} \mathrm{C}\right)$ during the cultivation of upland rice cultivars in 2008/2009 (A), 2009/2010 (B), 2010/2011 (C), 2011/2012 (D), and 2012/2013 (E).
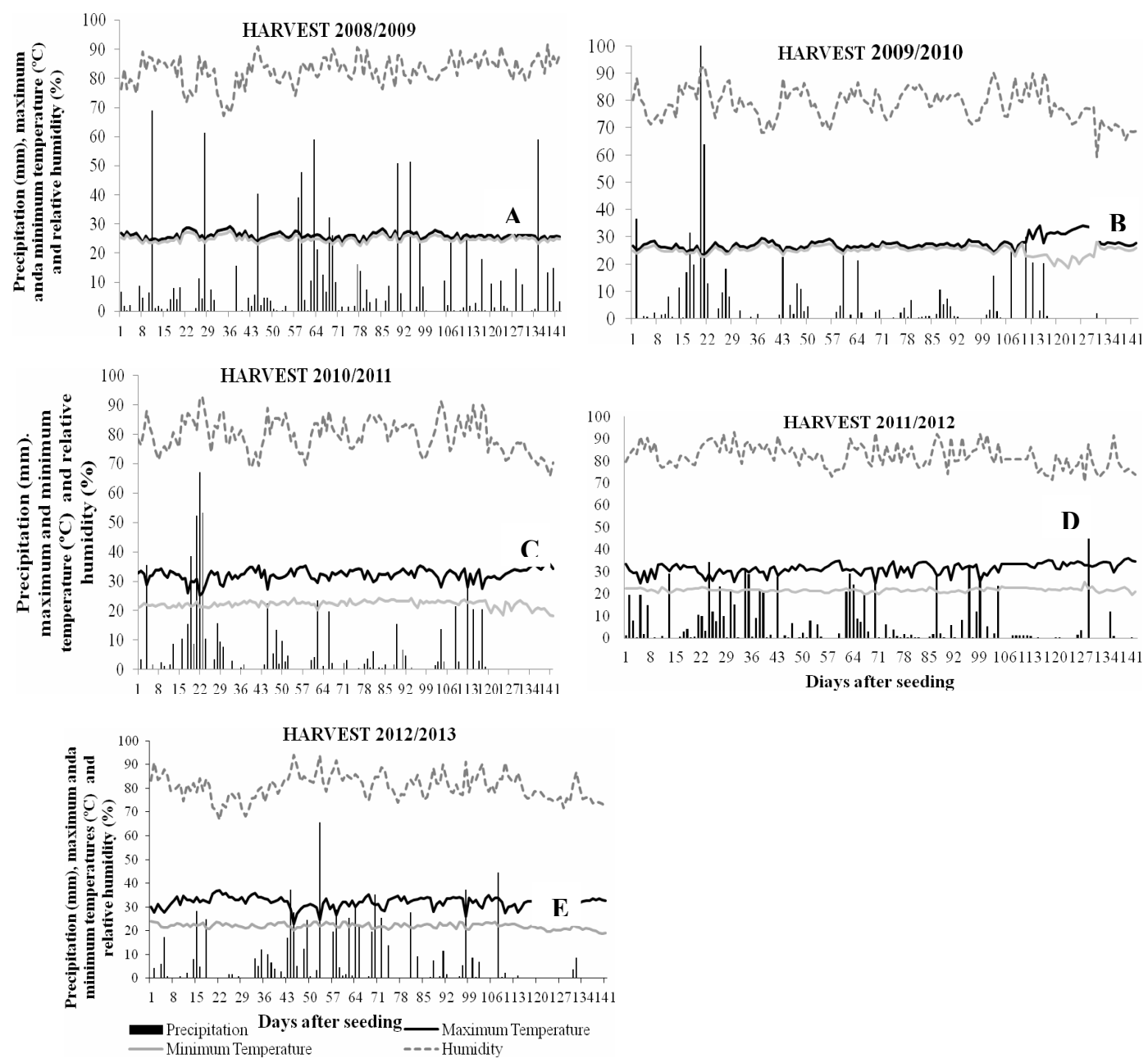

Source: (BDMEP, 2013). 
The areas used for the experiments in 2008/09 and 2009/10 had been used for many years as pastures and were in a degraded condition. Crop rotation (crop, rice; off-season crop, beans) was performed in the area used for the experiments in 2010/11, 2011/12, and 2012/13. At all the cultivation sites, liming was performed to correct soil acidity; however, in 2009, the limestone had no time to react, as shown in the chemical characteristics of the soil for the season, because the correction was performed just before sowing (Table 1). Prior to the start of the experiments, soil samples were collected from a depth of $0-20 \mathrm{~cm}$ in each year for characterization of physical and chemical attributes (Table 1).

Table 1. Chemical and physical properties of the soil at a depth of $0-20 \mathrm{~cm}$ in the experimental areas.

\begin{tabular}{|c|c|c|c|c|c|}
\hline \multirow{2}{*}{ Soil attributes } & \multicolumn{5}{|c|}{ Cropping years } \\
\hline & 08/09 & $09 / 10$ & $10 / 11$ & $11 / 12$ & $12 / 13$ \\
\hline $\mathrm{Ca}+\mathrm{Mg}\left(\mathrm{cmol}_{\mathrm{c}} \mathrm{dm}^{-3}\right)$ & 4,00 & 0,80 & 1,00 & 1,50 & 1,57 \\
\hline $\mathrm{K}\left(\mathrm{cmol}_{\mathrm{c}} \mathrm{dm}^{-3}\right)$ & 0,02 & 0,06 & 0,62 & 0,10 & 0,08 \\
\hline $\mathrm{BS}\left(\mathrm{cmol}_{\mathrm{c}} \mathrm{dm}^{-3}\right)$ & 4,02 & 0,86 & 1,62 & 1,70 & 1,63 \\
\hline $\mathrm{H}+\mathrm{Al}\left(\mathrm{cmol}_{\mathrm{c}} \mathrm{dm}^{-3}\right)$ & 3,30 & 4,10 & 3,32 & 1,30 & 1,02 \\
\hline $\mathrm{pH}\left(\mathrm{CaCl}_{2}\right)^{\mathrm{c}}$ & 4,60 & 5,00 & 5,7 & 6,10 & 6,30 \\
\hline P-melich $\left(\mathrm{mg} \mathrm{dm}^{-3}\right)$ & 80,00 & 1,20 & 10,30 & 15,60 & 11,12 \\
\hline $\mathrm{T}\left(\mathrm{cmol}_{\mathrm{c}} \mathrm{dm}^{-3}\right)$ & 7,32 & 4,49 & 4,94 & 3,00 & 2,65 \\
\hline$V(\%)$ & 54,91 & 19,15 & 32,92 & 55,20 & 61,40 \\
\hline O.M (\%) & 1,10 & 18,10 & 2,01 & 4,70 & 13,32 \\
\hline Sand $\left(\mathrm{g} \mathrm{kg}^{-1}\right)$ & 785,20 & 690,10 & 709,00 & 735,20 & 542,40 \\
\hline Silt $\left(\mathrm{g} \mathrm{kg}^{-1}\right)$ & 38,30 & 40,50 & 47,70 & 57,20 & 54,90 \\
\hline Clay $\left(\mathrm{g} \mathrm{kg}^{-1}\right)$ & 176,50 & 269,30 & 243,20 & 207,60 & 402,70 \\
\hline
\end{tabular}

The experiment was performed using a randomized block design with four replications, in a factorial scheme of $3 \times 5$ composed of the three genotypes and five years of cultivation. During cultivation in 2008/2009, each experimental plot consisted of five lines (length $5 \mathrm{~m}$; spacing, $0.45 \mathrm{~m}$ ) and 60 seeds per linear meter, using as the useful area the three core lines, despising 0.5 meters from each end and the two sidelines getting $5.4 \mathrm{~m}^{2}$ of useful area. For other crops, each experimental plot consisted of four rows $5 \mathrm{~m}$ in length (spacing, 0.45 $\mathrm{m})$ and 60 seeds per meter. As the useful area the two central lines with $4 \mathrm{~m}$ long was used, ignoring the two side lines and $0.5 \mathrm{~m}$ from each end totalling thus $3.6 \mathrm{~m}^{2}$ of useful area.

For the study, cultivars BRS Bonança, BRS Primavera, and BRSMG Conai were used, and the main characteristics of each cultivar are presented in Table 2. In all years, sowing was performed conventionally with heavy disk harrowing + level disking. Sowing was manually performed on December 10th, 2008, December 10th, 2009, December 11th, 2010, December 10th, 2011, and November 29th, 2012.

The sowing fertilization was held at the furrow according to soil analysis each year and the recommendation for rice growing at uplands. In the cropping period of $2008 / 09,120 \mathrm{~kg} \mathrm{ha}^{-1}$ of $\mathrm{P}_{2} \mathrm{O}_{5}$ was applied as triple superphosphate, and $60 \mathrm{~kg} \mathrm{ha}^{-1}$ of $\mathrm{K}_{2} \mathrm{O}$ was applied in the form of potassium chloride, discounting the fertilizer in the soil. In 2009/10, $120 \mathrm{~kg} \mathrm{ha}^{-1}$ of $\mathrm{P}_{2} \mathrm{O}_{5}$ was applied in the form of triple superphosphate and $90 \mathrm{~kg} \mathrm{ha}^{-1}$ of $\mathrm{K}_{2} \mathrm{O}$ as potassium chloride, also discounting the fertilizer in the soil. For the 2010/11 crop, $120 \mathrm{~kg} \mathrm{ha}^{-1}$ of $\mathrm{P}_{2} \mathrm{O}_{5}$ was applied in the form of simple superphosphate $\left(17 \% \mathrm{P}_{2} \mathrm{O}_{5}\right)$, 
discounting the $\mathrm{P}$ already present in the soil. $\mathrm{K}$ was applied during planting at a dosage of $60 \mathrm{~kg} \mathrm{ha}^{-1}$ of $\mathrm{K}_{2} \mathrm{O}$ in the form of potassium chloride. In 2011/12 and 2012/13, a formulated chemical fertilizer, NPK 5-25-15, was used, and $360 \mathrm{~kg} \mathrm{ha}^{-1}$ and $400 \mathrm{~kg} \mathrm{ha}^{-1}$, respectively, were applied to the furrows.

Table 2. Main features of the three cultivars.

\begin{tabular}{cccccc}
\hline Cultivars & $\begin{array}{c}\text { Plant height } \\
\text { (cm) }\end{array}$ & $\begin{array}{c}\text { Flowering } \\
\text { (days) }\end{array}$ & $\begin{array}{c}\text { Cycle } \\
\text { (days) }\end{array}$ & Bedding & $\begin{array}{c}\text { Grain } \\
\text { classification }\end{array}$ \\
\hline BRS-Bonança & 96 & 80 & 115 & Resistant & $\begin{array}{c}\text { Long thin or } \\
\text { mixed }\end{array}$ \\
BRS-Primavera & 107 & 72 & 107 & $\begin{array}{c}\text { Moderately } \\
\text { susceptible } \\
\text { Resistant }\end{array}$ & $\begin{array}{c}\text { Long thin } \\
\text { BRSMG-Conai }\end{array}$ \\
\hline
\end{tabular}

Source: Embrapa Arroz e Feijão e Epamig.

Fertilization in the cropping periods of 2008/09 and 2009/10 was performed with $120 \mathrm{~kg} \mathrm{ha}^{-1}$ of $\mathrm{N}$ in the form of urea. In 2010/11, $120 \mathrm{~kg} \mathrm{ha}^{-1}$ of $\mathrm{N}$ was applied as urea and boron; in 2011/12 and 2012/13, $120 \mathrm{~kg} \mathrm{ha}^{-1} \mathrm{~N}$ was applied, discounting $\mathrm{N}$ fertilization performed in the furrows. For all crops, fertilization was performed in two stages. The first stage was upon effective tillering, about 30 days after sowing, and the second stage, at panicle differentiation, about 60 days after sowing.

The cropping needs in 2008/09 and 2009/10 were implemented when necessary, and weed control, performed by hand, was always conducted before fertilization. In 2010/11, four herbicide applications, with fenoxaprop (narrow leaf) and 2,4-D amine (broad leaf), were used for weed control, according to the recommendations suitable for rice cultivation. In 2011/12, the cropping needs were implemented by applying a pre-emergent herbicide, oxifluorfem (240 g ai ha $\mathrm{g}^{-1}$ ), to control the weeds. Before coverage amendment, post-emergent application using Bentazon (600 $\mathrm{g}$ ai ha $\mathrm{h}^{-1}$ ) was performed. In addition to the cropping needs, manual weeding was carried out shortly after flowering. In 2012/13, the pre-emergent herbicide oxifluorfem ( $240 \mathrm{~g}$ ai ha$\left.{ }^{1}\right)$ was applied the same day of planting for weed control. The post-emergent herbicide used was fenoxaprop-P-ethyl 6.9 CE before flowering. In addition, manual weeding was performed shortly after flowering. There was no need for insecticides and fungicides in any of the growing seasons.

The evaluated characteristics were as follows: number of days to flowering; days to the emission of $50 \%$ of panicles from the date of sowing; plant height measured from the soil surface to the apex of the panicle of the central stem, excluding the awn when present; hundred-grain mass, mass of a sample of one hundred healthy grains per plot; and grain yield, production of clean grains with $13 \%$ moisture in $\mathrm{kg} \mathrm{ha}^{-1}$.

The experimental data were evaluated using individual and joint statistical analyses of variance and the $\mathrm{F}$ test. The joint analyses were performed under homogeneous conditions of residual variances. For comparisons between the means values of the treatments, Tukey's test $(p<0.05)$ was used with the computer program SISVAR (FERREIRA, 2008).

\section{Results and Discussion}

According to the variance analysis results (Table 3), significance of the interaction between cultivar and years for all traits was detected. The results showed interdependence of the factors; in 
other words, the years influenced the expression of agronomic traits in the studied cultivars differently. The significance of all the characteristics was observed, for both cultivar factor and year factor (Table 3), confirming the genetic variability among the cultivars as well as variations in the years of cultivation. Cargnin et al. (2008) and Cancellier et al. (2011) also obtained similar results, highlighting the importance of studies that evaluated cultivars behaviour over several years with the aim of identifying genetic materials more adapted and with high productive potential in the face of soil and climatic diversity for each crop.

Table 3. Variance analysis of the average number of days to flowering (DF), plant height (PH) mass of one hundred grains (MHG), and grain yield (YD) of the three rice cultivars grown in 2008/2009, 2009/2010, 2010/2011, 2011/2012, and 2012/2013 in Gurupi-Tocantins.

\begin{tabular}{lccccc}
\hline \multirow{2}{*}{ Variation Source } & \multirow{2}{*}{ GL } & \multicolumn{4}{c}{ Mean Square } \\
\cline { 2 - 5 } & & DF (days) & PH $(\mathrm{cm})$ & MHG $(\mathrm{g})$ & YD $\left(\mathrm{kg} \mathrm{ha}^{-1}\right)$ \\
\hline Repetition (year) & 15 & $30,82^{*}$ & $36,46^{\mathrm{ns}}$ & $0,09^{\text {ns }}$ & $521497,07^{\mathrm{ns}}$ \\
Cultivar (C) & 2 & $755,62^{* *}$ & $1056,00^{* *}$ & $4,38^{* *}$ & $2124669,65^{* *}$ \\
Year (Y) & 4 & $363,13^{* *}$ & $1309,25^{* *}$ & $2,26^{* *}$ & $7943441,11^{* *}$ \\
CxY & 8 & $44,99^{* *}$ & $110,75^{* *}$ & $4,29^{* *}$ & $650759,86^{*}$ \\
Residue & 30 & 13,72 & 19,91 & 0,13 & 283422,93 \\
\hline VC (\%) & 4,99 & 5,54 & 13,68 & 46,57 \\
General Mean & & 74,19 & 80,55 & 2,65 & 1143,18 \\
\hline
\end{tabular}

${ }^{\mathrm{ns}}$ not significant; ${ }^{* *}$ significant for $\mathrm{p} \leq 0,01$; ${ }^{*}$ significant for $\mathrm{p} \leq 0,05$ according to the F test.

The low values of coefficients of variation (CV) reflect the reliability of the obtained results (Table 3). Although the characteristic grain yield displayed high CV (46.57\%), it was not considered incongruous. According to Costa et al. (2002), the nature of the studied variable reflects the value of $\mathrm{CV}$ subjected to variations in uncontrolled factors. In addition, the randomized block design tends to increase the value of CV. High CV values for grain yield were also found in studies performed by Tonello et al. (2012) (CV, 45.88\%), Cancellier et al. (2011) (CV, 30.76\%), and Sousa et al. (2012) (CV, $30.20 \%)$.

The average values for the characteristic number of days to flowering are presented in Table 4. BRSBonança had a later cycle in each year of cultivation, although it did not differ significantly from the cycle of BRS-Primavera in 2010/11, 2011/12, and 2012/13. BRSMG-Conai showed the earliest cycle in most years and did not differ from BRS-
Primavera in only 2008/09. According to Crusciol et al. (2003b), cultivars with a shorter cycle favour cultivation systems with crop succession, such as those used in the off-season, and reduce irrigation costs and allowing that these escape of possible drawn out over the cultivation period.

With respect to the years of cultivation (Table 4), the 2009/10 crop showed the highest mean for the three evaluated cultivars; in other words, cycle extension of the genetic material was observed, showing that which despite being a characteristic of the cultivar, genetic material can be influenced by the environment. Crusciol et al. (2003b) and Arf et al. (2001) have reported that upland rice crop tends to show an increase in the number of days to $50 \%$ flowering under conditions of reduced water availability. Heinemann and Stone (2009) and Terra et al. (2013) also found an increase in the number of days to flowering in upland rice cultivars subjected to water stress. 
Table 4. Average of the number of days to flowering of the three upland rice cultivars in the southern region of the state of Tocantins in the cropping periods of 2008/2009, 2009/2010, 2010/2011, 2011/2012, and 2012/2013.

\begin{tabular}{lcccccc}
\hline & \multicolumn{5}{c}{ Days to flowering (days) } \\
\cline { 2 - 6 } Cultivar & Season 08/09 & Season 09/10 & Season 10/11 & Season 11/12 & Season 12/13 & Mean \\
\hline BRS-Bonança & $83,75 \mathrm{aB}$ & $92,25 \mathrm{aA}$ & $72,60 \mathrm{aC}$ & $78,50 \mathrm{aBC}$ & $75,00 \mathrm{aC}$ & 80,42 \\
BRS-Primavera & $71,00 \mathrm{bB}$ & $81,75 \mathrm{bA}$ & $73,90 \mathrm{aB}$ & $73,50 \mathrm{aB}$ & $70,00 \mathrm{abB}$ & 74,03 \\
BRSMG-Conai & $72,25 \mathrm{bAB}$ & $74,75 \mathrm{cA}$ & $60,65 \mathrm{bC}$ & $67,00 \mathrm{bBC}$ & $66,00 \mathrm{bBC}$ & 68,13 \\
\hline Mean & 75,66 & 82,91 & 69,05 & 73,00 & 70,33 & \\
\hline
\end{tabular}

Means followed by the same lowercase letter in the columns and capitals in the lines do not differ according to Tukey's test $(\mathrm{p} \leq$ $0.05)$.

With respect to plant height (Table 5), BRSPrimavera showed the largest values in every growing year, despite not having differed from BRS-Bonança in the 2010/11 season. Thus, plant height is also intrinsic to the cultivar; however, it can be influenced by non-controllable environmental factors, resulting in variations from crop to crop.

Table 5. Plant height means of the three upland rice cultivars in the southern region of the state of Tocantins in the cropping periods of 2008/2009, 2009/2010, 2010/2011, 2011/2012, and 2012/2013.

\begin{tabular}{lcccccc}
\hline & \multicolumn{7}{c}{ Plant height $(\mathrm{cm})$} \\
\cline { 2 - 6 } Cultivar & Season 08/09 & Season 09/10 & Season 10/11 & Season 11/12 & Season 12/13 & Mean \\
\hline BRS-Bonança & $65,90 \mathrm{bD}$ & $72,15 \mathrm{bCD}$ & $75,75 \mathrm{aBC}$ & $82,70 \mathrm{bB}$ & $92,52 \mathrm{bA}$ & 77,80 \\
BRS-Primavera & $85,65 \mathrm{aB}$ & $86,40 \mathrm{aB}$ & $71,00 \mathrm{abC}$ & $93,87 \mathrm{aB}$ & $107,05 \mathrm{aA}$ & 88,79 \\
BRSMG-Conai & $69,72 \mathrm{bBC}$ & $75,65 \mathrm{bB}$ & $64,75 \mathrm{bC}$ & $73,32 \mathrm{cBC}$ & $91,87 \mathrm{bA}$ & 75,06 \\
\hline Mean & 73,75 & 78,06 & 70,50 & 83,30 & 97,15 & \\
\hline
\end{tabular}

Means followed by the same lowercase letter in the columns and capitals in the lines do not differ according to Tukey's test ( $\mathrm{p} \leq$ $0.05)$.

The 2012/13 cropping season showed the highest plant height means for the three evaluated cultivars (Table 5); this can be correlated with the highest rainfall averages and the fact that rainfall was better distributed, favouring the production of biomass for the cultivar. Despite the greater heights of plants in that cropping year, exceeding $1 \mathrm{~m}$, bedding plants were observed. According to Taiz and Zeiger (2013), reduced plant height is associated with reduced photosynthetic rate, reduced cell growth, and several morphological, physiological, and biochemical changes, leading to negative effects on biomass production as the plants do not obtain an adequate supply of water for development; this may explain the lower plant heights in the other cropping years. According to Crusciol et al. (2003b), Terra et al. (2013), and Nunes et al. (2012), drought stress changes the physiology of plants and reduces their heights, and depending on the intensity of the occurrence of stress in combination with other factors, the impact can be greater or lesser on the culture and final yield.

For mass of a hundred grains, Table 6 shows that that the cultivar BRSMG-Conai always showed higher means than the other cultivars, except in 2011/12, in which BRS-Primavera showed a statistically higher mean value than the other cultivars.

Few differences in the mean mass of one hundred grains were observed for all cultivars in all the years of cultivation (Table 6), and the values were not affected by the influence of precipitation in each year. The high value for the mass of a hundred 
grains for BRS-Primavera in the cropping period of 2011/12 may have been influenced by the low tillering of the crop in that season; thus, any product of photosynthesis was directed to a smaller number of grains, making them heavier.
Mean values for the trait grain yield are shown in Table 7. The BRS-Primavera cultivar was always the most productive, although there was no significant difference in yields in 2008/09, 2009/10, and 2010/11.

Table 6. Mean mass of one hundred grains of the three rice cultivars grown in the uplands south of the state of Tocantins in the cropping periods of 2008/2009, 2009/2010, 2010/2011, 2011/2012, and 2012/2013.

\begin{tabular}{lcccccc}
\hline & \multicolumn{5}{c}{ Mass of a hundred grains $(\mathrm{g})$} \\
\cline { 2 - 7 } Cultivar & Season 08/09 & Season 09/10 & Season 10/11 & Season 11/12 & Season 12/13 & Mean \\
\hline BRS-Bonança & $2,35 \mathrm{bA}$ & $2,58 \mathrm{aA}$ & $2,55 \mathrm{bA}$ & $1,94 \mathrm{bAB}$ & $1,29 \mathrm{bB}$ & 2,14 \\
BRS-Primavera & $2,27 \mathrm{bB}$ & $2,29 \mathrm{aB}$ & $2,71 \mathrm{bB}$ & $5,63 \mathrm{aA}$ & $2,42 \mathrm{aB}$ & 3,06 \\
BRSMG-Conai & $3,18 \mathrm{aA}$ & $2,80 \mathrm{aAB}$ & $3,43 \mathrm{aA}$ & $2,01 \mathrm{bC}$ & $2,37 \mathrm{aBC}$ & 2,76 \\
\hline Mean & 2,60 & 2,56 & 2,89 & 3,19 & 2,03 & \\
\hline
\end{tabular}

Means followed by the same lowercase letter in the columns and capitals in the lines do not differ according to Tukey's test ( $\mathrm{p} \leq$ $0.05)$.

Table 7. Mean grain productivity of the three upland rice cultivars in the southern state of Tocantins in the cropping periods of 2008/2009, 2009/2010, 2010/2011, 2011/2012, and 2012/2013.

\begin{tabular}{lcccccc}
\hline \multirow{2}{*}{ Cultivar } & \multicolumn{7}{c}{ Grain Productivity $\left(\mathrm{kg} \mathrm{ha}^{-1}\right)$} \\
\cline { 2 - 7 } & Season 08/09 & Season 09/10 & Season 10/11 & Season 11/12 & Season 12/13 & Mean \\
\hline BRS-Bonança & $748,80 \mathrm{aAB}$ & $511,48 \mathrm{aB}$ & $847,76 \mathrm{aAB}$ & $698,60 \mathrm{abAB}$ & $1754,16 \mathrm{bA}$ & 912,16 \\
BRS-Primavera & $1098,19 \mathrm{aB}$ & $687,77 \mathrm{aB}$ & $1193,36 \mathrm{aB}$ & $1558,33 \mathrm{aB}$ & $3042,34 \mathrm{aA}$ & 1516 \\
BRSMG-Conai & $304,98 \mathrm{aB}$ & $778,51 \mathrm{aB}$ & $635,58 \mathrm{aB}$ & $319,43 \mathrm{bB}$ & $2968,45 \mathrm{aA}$ & 1001,39 \\
\hline Mean & 717,32 & 659,25 & 892,23 & 858,79 & 2588,32 & \\
\hline
\end{tabular}

Means followed by the same lowercase letter in the columns and capitals in the lines do not differ according to Tukey's test ( $\mathrm{p} \leq$ $0.05)$.

Cropping year 2012/13 showed the highest average grain yield for all cultivars. This shows the influence of rainfall during the cultivation of this crop; the rainfall was better distributed in that period (Figure 1). According Taiz and Zeiger (2013), translocation of photo-assimilates and whole-plant metabolism are influenced and dependent on the water factor, being essential for the satisfactory functioning of the plant system; therefore, a deficit of this resource limits and inhibits certain functions and compromises culture yield.

The rice crop yield may show greater or lesser impacts of drought on the basis of the occurrence intensity and life cycle period in which the culture was subjected to that stress. The most important stages considered critical are the flowering and grainfilling phases of rice cultivation (HEINEMANN; STONE, 2009). Crusciol et al. (2001), Silva et al. (2009), and Nunes et al. (2012) verified a correlation between grain yield and spikelet sterility. The latter occurs with great intensity when the crop is under water stress. In addition to reducing the number of spikelets per panicle, the number of panicles per $\mathrm{m}^{2}$ is reduced, and these factors affect the final productivity of the culture.

It is evident that the BRS-Primavera cultivar showed the highest grain yield in all the cropping years, with values ranging from 687.77 to 3042.34 
$\mathrm{kg} \mathrm{ha}^{-1}$ (Table 7). When the performances of the cultivars in each year were compared, better productive performance during the harvest and a larger volume and distribution of water for plants during the flowering period were observed in 12/13.

\section{Conclusions}

The highest grain yields of upland rice were achieved in the cropping period of 2012/13, which showed the highest volume and better distribution of rainfall. The flowering time was lesser and greater for BRSMG-Conai and BRS-Bonança cultivars, respectively. The BRS-Primavera cultivar showed the highest grain yield in different years in Cerrado vegetation soil in the south of the State of Tocantins.

\section{Acknowledgements}

The Upper Level Personnel Enhancement Coordination (CAPES) and Federal University of Tocantins.

\section{References}

ARF, O.; RODRIGUES, R. A. F.; SÁ, M. E.; CRUSCIOL, C. A. C. Resposta de cultivares de arroz de sequeiro ao preparo do solo e à irrigação por aspersão. Pesquisa Agropecuária Brasileira, Brasília, v. 36, n. 6, p. 871-879, 2001.

BANCO DE DADOS METEORÓLOGICOS PARA ENSINO E PESQUISA - BDMEP. Banco de dados. Brasília: INMET/MAPA, 2013. Disponível em: $<$ http:// www.inmet.gov.br>. Acesso em: 28 nov. 2013.

CANCELLIER, E. L.; BARROS, H. B.; KISCHEL, E.; GONZAGA, L. A. M.; BRANDÃO, D. R.; FIDELIS, R. R. Eficiência agrônomica no uso de nitrogênio mineral por cultivares de arroz de terras altas. Revista Brasileira de Ciências Agrárias, Recife, v. 6, n. 4, p. 650-656, 2011.

CARGNIN, A.; SOUZA, M. A.; PIMENTEL, A. J. B.; FOGAÇA, C. M. Interação genótipos e ambientes e implicações na adaptabilidade e estabilidade de arroz sequeiro. Revista Brasileira Agrociência, Pelotas, v. 14, n. 3-4, p. 49-57, 2008.

COMPANHIA NACIONAL DE ABASTECIMENTO CONAB. Acompanhamento de safra brasileira de grãos
14/15 décimo primeiro levantamento. Brasília: CONAB, ago. 2015. Disponível em: <http://www.conab.gov.br>. Acesso em: 8 mar. 2015.

COSTA, N. H. de A. D.; SERAPHIN, J. C.; ZIMMERMANN, F. J. P. Novo método de classificação de coeficientes de variação para a cultura do arroz de terras altas. Pesquisa Agropecuária Brasileira, Brasília, v. 37, n. 3, p. 243-249, 2002.

CRUSCIOL, C. A. C.; ARF, O.; SORATTO, R. P.; ANDREOTTI, M. Produtividade do arroz de terras altas sob condições de sequeiro e irrigado por aspersão em função do espaçamento entre fileiras. Agronomia, Rio de Janeiro, v. 37, n. 1, p. 10-15, 2003 b.

CRUSCIOL, C. A. C.; ARF, O.; SORATTO, R. P.; RODRIGUES, R. A. F.; MACHADO, J. R. Manejo de irrigação por aspersão com base no "Kc" e adubação mineral na cultura de arroz de terras altas. Bragantia, Campinas, v. 62, n. 3, p. 465-75, 2003a.

CRUSCIOL, C. A. C.; ARF, O.; ZUCARELI, C.; SÁ, M. E.; NAKAGAWA, J. Produção e qualidade fisiológica de sementes de arroz de terras altas em função da disponibilidade hídrica. Revista Brasileira de Sementes, Brasília, v. 23, n. 2, p. 287-293, 2001.

EMPRESA BRASILEIRA DE PESQUISA AGROPECUÁRIA - EMBRAPA. Centro Nacional de Pesquisa de Solos. Sistema Brasileiro de Classificação de Solos. 3. ed. rev. ampl. Brasília: EMBRAPA, 2013. $353 \mathrm{p}$.

FERREIRA, D. F. SISVAR: um programa para análises e ensino de estatística. Revista Symposium, Lavras, v. 6, n. 2, p. 36-41, 2008.

GUIMARÃES, C. M.; STONE, L. F.; NEVES, P. C. F. Eficiência produtiva de cultivares de arroz com divergência fenotípica. Revista Brasileira Engenharia Agrícola e Ambiental, Campina Grande, v. 12, n. 5, p. 465-470, 2008.

HEINEMANN, A. B.; STONE, L. F. Efeito da deficiência hídrica no desenvolvimento e rendimento de quatro cultivares de arroz de terras altas. Pesquisa Agropecuária Tropical, Goiânia, v. 39, n. 2, p. 134-139, 2009.

KÖPPEN, W. Climatologia: con un estúdio de los climas de la terra. México: Fondo de Cultura Económica, 1948. $479 \mathrm{p}$.

MELO, L. C.; MELO, P. G. S.; FARIA, L. C.; DIAZ, J. L. C.; PELOSO, M. J. D.; RAVA, C. A.; COSTA, J. G. C. Interação com ambientes e estabilidade de genótipos de feijoeiro-comum na Região Centro-Sul do Brasil. Pesquisa Agropecuária Brasileira, Brasília v. 42, n. 5, p. 715-723, 2007. 
MORAIS, L. K.; SILVA, R. M.; CHIORATO, A. F.; AZZINI, L. E.; VILLELA, O. V.; GALLO, P. B.; SAKAI, M.; BASTOS, C. R.; MALAVOLTA, V. M. A. Adaptabilidade e estabilidade fenotípica de genótipos de arroz irrigado para o Estado de São Paulo. Revista Biociências, Campinas, v. 14, n. 1, p. 9-16, 2008.

NOSSE, T. O.; AQUINO, S. S.; CAZETTA, D. A.; ARF, O.; CASSIOLATO, A. M. R. Restos vegetais e adubação nitrogenada na micorrização e produtividade do arroz de terras altas em sistema plantio direto. Acta Scientiarum: Agronomy, Maringá, v. 30, n. 4, p. 547-553, 2008.

NUNES, T. V.; ADORIAN, G. C.; TERRA, T. G. R.; LEAL, T. C. A. de B.; SANTOS, A. C.; RAMOS, P. da $\mathrm{S}$. Aspectos produtivos de linhagens de arroz de terras altas sob déficit hídrico. Revista Brasileira de Ciências Agrárias, Recife, v. 7, n. 1, p. 51-57, 2012.

PIRES, L. P. M.; PELUZIO, J. M.; CANCELLIER, L. L.; RIBEIRO, G. R.; COLOMBO, G. A.; AFFÉRRI, F. S. Desempenho de genótipos de soja, cultivados na região centro-sul do estado do Tocantins, safra 2009/2010. Bioscience Journal, Uberlândia, v. 28, n. 2, p. 214-223, 2012.
SILVA, E. A.; SORATTO, R. P.; ADRIANO, E.; BISCARO, G. A. Avaliação de cultivares de arroz de Terras Altas sob condições de sequeiro em Cassilândia, MS. Ciência e Agrotecnologia, Lavras, v. 33, n. 1, p. 298304, 2009.

SOUSA, S. A.; SILVA, J.; VENÂNCIO, J. L.; OLIVEIRA, T. C.; BARROS, H. B.; FIDELIS, R. R. Efeito do nitrogênio em genótipos de feijão cultivados em várzea úmida irrigada do Estado do Tocantins. Journal of Biotechnology and Biodiversity, Gurupi, v. 3, n. 2, p. 80-88, 2012.

TAIZ, L.; ZEIGER, E. Fisiologia vegetal. 5. ed. Porto Alegre: Artmed, 2013. 918 p.

TERRA, T. G. R.; LEAL, T. C. A. B.; BORÉM, A.; RANGEL, P. H. N. Tolerância de linhagens de arroz de terras altas à seca. Pesquisa Agropecuária Tropical, Goiânia, v. 43, n. 2, p. 201-208, 2013.

TONELLO, L. P.; SILVA, J.; RAMOS, D. P.; SOUZA, S. A.; FIDELIS, R. R. Eficiência do uso de fósforo em genótipos de arroz cultivados em solos de terras altas. Revista Verde, Mossoró, v. 7, n. 2, p. 25-32, 2012. 